\title{
REKONSTRUKSI PERTIMBANGAN HAKIM TERHADAP PUTUSAN SENGKETA PERDATA BERBASIS NILAI KEADILAN
}

\author{
Pandu Dewanto \\ Pengadilan Negeri Mojokerto, Mojokerto \\ pandu44dewanto@gmail.com
}

\begin{abstract}
Abstrak
Tujuan penelitian ini adalah untuk menganalisis bagaimana sistem hukum Pancasila sebagai prinsip pertimbangan hakim terhadap sengketa para pihak dan bagaimana rekonstruksi prinsip pertimbangan hakim terhadap sengketa para pihak berbasis nilai keadilan. Rekonstruksi nilai dalam Pasal 5 ayat (1) Undang-Undang Nomor 48 Tahun 2009, "Hakim dan hakim konstitusi wajib menggali, mengikuti, dan memahami nilai-nilai hukum dan rasa keadilan yang hidup dalam masyarakat". Dalam Pasal tersebut mewajibkan hakim sebagai penegak hukum dan keadilan untuk menggali dan memahami nilai-nilai hukum yang hidup dalam masyarakat. Pada prinsipnya hakim tidak diberi wewenang untuk mengubah suatu undang-undang akan tetapi hakim guna menjatuhkan putusannya yang berdasar pada perkembangan kehidupan dalam masyarakat dengan tidak menerapkan undang-undang tersebut. Metode penelitian yang digunakan pada penelitian ini adalah paradigma konstruktivisme. Merekonstruksi norma hukum dalam Pasal 5 Ayat (1) Undang-Undang Nomor 48 Tahun 2009 Tentang Kekuasaan Kehakiman, menjadi berbunyi: Hakim dan hakim konstitusi wajib menggali, mengikuti, dan memahami nilai-nilai hukum dengan cara merekonstruksi hukum, menafsirkan hukum, dan menemukan hukum untuk memberi rasa keadilan yang hidup dalam masyarakat. Temuan teori hukum barunya adalah: "Penemuan Hukum yang Berkeadilan dan Bermartabat", artinya pertimbangan hakim dalam memutus perkara ukurannya adalah keadilan, yaitu seorang hakim dalam menggali/mencari keadilan itu sendiri dengan caranya merekonstruksi hukum, menafsirkan hukum, dan menemukan hukum.
\end{abstract}

Kata Kunci: Rekonstruksi; Pertimbangan Hakim; Putusan Sengketa Perdata 


\title{
RECONSTRUCTION OF JUDGE'S CONSIDERATION OF CIVIL DISPUTE VERDICT BASED ON VALUE OF JUSTICE
}

\author{
Pandu Dewanto \\ Penagdilan Negeri Mojokerto, Mojokerto \\ pandu44dewanto@gmail.com
}

\begin{abstract}
The purpose of this research is to analyze how pancasila legal system as the principle of consideration of judges against disputes of the parties and how the reconstruction of the principle of consideration of judges against disputes of the parties based on the value of justice. Reconstruction of the value in Article 5 paragraph (1) of Law No. 48 of 2009, "Judges and judges of the constitution shall dig, follow, and understand the values of law and the sense of justice that lives in society". The Article requires judges as law enforcement and justice to dig in and understand the legal values that live in society. In principle the judge is not authorized to change a law but the judge to overturn his verdict based on the development of life in society by not applying the law. The research method used in this study is a paradigm of constructivism. Reconstructing the legal norms in Article 5 Paragraph (1) of Law No. 48 of 2009 on judicial power, it reads: Judges and constitutional judges are obliged to dig, follow, and understand the values of the law by reconstructing the law, interpreting the law, and finding laws to give a sense of justice that lives in society. The findings of his new legal theory are: 'The Discovery of a Just and Dignified Law', which means that the judge's consideration in in deciding cases is justice, i.e. a judge in digging/seeking justice himself by reconstructing the law, interpreting the law, and finding the law.
\end{abstract}

Keywords: Reconstruction; Judge's Consideration; Civil Dispute Decision 
p-ISSN : 2541-2345, e-ISSN : 2580-8842

\section{PENDAHULUAN}

\section{A. Latar Belakang}

Para hakim dalam proses mengadili dan menjatuhkan putusan wajib memadukan atau menggabungkan kepentingan hukum dan sekaligus kepentingan keadilan, dalam arti putusan hukum itu di dalamnya harus mengandung substansi keadilan atau putusan hukum yang berintikan keadilan. Fungsi hakim dalam Negara Hukum Republik Indonesia bukan hanya selaku penerap atau pelaksana peraturan perundang-undangan, melainkan wajib hukumnya untuk bertindak selaku penemu hukum dan atau selaku pencipta hukum, sehingga putusan yang dijajatuhkan oleh para hakim sungguh-sungguh mencerminkan rasa keadilan berdasrkan Pancasila. ${ }^{1}$ Hakim merupakan pilar utama dan tempat terakhir bagi pencari keadilan dalam proses peradilan sebagai salah satu elemen kekuasaan kehakiman yang menerima, memeriksa, dan memutus perkara, hakim dituntut untuk memberikan keadilan kepada para pencari keadilan. ${ }^{2}$

Pertimbangan hakim terhadap sengketa para pihak dalam sistem hukum Indonesia, bahwa pada prinsipnya putusan pengadilan dalam perkara perdata pasti ada pihak yang dimenangkan dan pihak yang dikalahkan. Akan tetapi pihak yang kalah sering di hukum terlalu tinggi dengan mengabulkan seluruh permintaan pihak yang menang, sehingga pada akhirnya pihak yang kalah sering menempuh upaya hukum karena tidak menerima putusan pengadilan tersebut. Seharusnya kalau putusan tersebut sudah berkeadilan, maka pihak yang kalah tidak akan menempuh upaya hukum lagi. Putusan perdata itu harus dapat mengakomodir kedua belah pihak meskipun salah satu pihak dinyatakan sebagai perbuatan melawan hukum dan/atau wanprestasi, akan tetapi dalam pemenuhan kerugiannya tidak memberatkan pihak yang kalah sehingga pihak yang kalah tersebut tidak terima dan mengajukan upaya

${ }^{1}$ Kuffal, HMA. Demi Keadilan Berdasarkan Ketuhanan Yang Maha Esa Hakim: Antara Gaji, Keadilan,Kejujuran dam Ketaqwaan, UMM Press. 2012, Malang, hal.40-41.

${ }^{2}$ Wildan Suyuti Mustofa, Kode Etik Hakim, Kencana Prenadamedia Group, Jakarta, 2013, hal. 55 . 
hukum. Hakim harus dapat mempertimbangkan segala aspek baik dari sisi penggugat maupun tergugat sehingga ketika hakim menjatuhkan putusan, pihak yang kalah tidak merasa sangat kalah. Dalam menangani sengketa perdata di pengadilan masih ada yang mengabaikan keadilan hukum, kepastian hukum dan kemanfaatan hukum.

Penelitian ini masih terkait dengan penelitian yang dilakukan oleh Sri Hartini, Setiati Widihastuti, dan Iffah Nurhayati (2017) yaitu meneliti tentang masih adanya keputusan hakim yang tidak berkeadilan dalam memutus perkara sengketa perdata menjadi salah satu alasan diangkatnya penelitian ini. Suatu perkara/sengketa diajukan oleh pihak yang merasa dirugikan kepada pengadilan untuk mendapatkan penyelesaian atau pemecahan. Pemeriksaan perkara memang diakhiri dengan putusan, akan tetapi dengan dijatuhkannya putusan saja belumlah selesai persoalannya. Putusan itu harus dapat dilaksanakan atau dijalankan (eksekusi). Suatu putusan pengadilan tidak ada artinya bagi pihak yang dimenangkan apabila tidak dilaksanakan. Oleh karena itu putusan hakim mempunyai kekuatan eksekutorial, yaitu kekuatan untuk dilaksanakan apa yang ditetapkan dalam putusan itu secara paksa oleh alatalat negara. ${ }^{3}$ Penelitian yang dilakukan oleh Sri Hartini, Setiati Widihastuti, dan Iffah Nurhayati tersebut lebih fokus dalam proses eksekusi dalam sengketa perdata dan hambatan-hambatan yang ada dalam proses eksekusi sengketa perdata.

Kebebasan dalam melaksanakan wewenang yudisial tidak mutlak sifatnya karena tugas hakim adalah menegakkan hukum dan keadilan berdasarkan Pancasila, dengan jalan menafsirkan hukum dan mencari dasardasar serta asas-asas yang jadi landasannya, melalui perkara-perkara yang dihadapkan kepadanya sehingga keputusannya mencerminkan perasaan keadilan bangsa dan rakyat Indonesia. Ning Adiasih (2017) dalam

${ }^{3}$ Sri Hartini, Setiati Widihastuti, dan Iffah Nurhayati, Eksekusi Putusan Hakim Dalam Sengketa Perdata Di Pengadilan Negeri Sleman, Jurnal Civics Vol 14 N0 2 Oktober 2017, Fakultas Ilmu Sosial Universitas Negeri Yogyakarta, 2017, Yogyakarta, hal 128-129. DOI: https://doi.org/10.21831/civics.v14i2.16852 
penelitiannya tersebut lebih fokus meneliti mengenai putusan hakim dalam perkasra perdata yang belum diatur dalam peraturan perundang-undangan. Kesimpulan dari penelitian tersebut seorang hakim dalam menghadapi suatu perkara yang peraturan perundang-undangannya tidak jelas, hakim tidak boleh menolak dengan dalih karena undang-undangnya tidak jelas, melainkan harus memeriksa, mengadili dan memutuskan dengan cara melakukan interpretasi hukum terhadap ketentuan yang sudah ada dengan memperhatikan nilai dan rasa keadilan yang ada dalam masyarakat. Contoh kasus dimana hakim dapat menerapkan asas-asas tersebut adalah saat menangani kasus Warisan yang diberikan dengan Wasiat Wajibah kepada ahli waris yang tidak berhak mendapatkan harta peninggalan. ${ }^{4}$

Berbeda dengan penelitian yang dilakukan oleh Jemmy Saut (2015), dalam penelitiannya tersebut lebih membahas mengenai putusan hakim perkara perdata dalam proses mediasi. Penelitian ini lebih banyak menguraikan tentang pentingnya mediasi dalam upaya penyelesaian perkara perdata di pengadilan, dan bagaimana proses dari mediasi tersebut mempunyai jaminan kepastian hukum para pihak yang bersengketa dalam kasus perdata. Jika dalam proses mediasi tercapai kesepakatan maka putusan hakim mempunyai kekuatan yang mengikat dan mempunyai kekuatan eksekutorial. Penyelesaian perkara perdata melalui proses mediasi diharapkan dapat mengurangi penumpukan berkas perkara di pengadilan, keuntungan lain yang diperoleh dengan penyelesaian perkara perdata melalui mediasi dapat berjalan dengan cepat dan murah jika dibandingkan melalui jalur litigasi. ${ }^{5}$

Proses penyelesaian melalui mediasi sendiri juga memupnyai banyak hambatan. Untuk dapat mencapai suatu kesepakatan atau titik temu dalam

\footnotetext{
${ }^{4}$ Ning Adiasih, Analisis Terhadap Putusan Pengadilan Dalam Perkara Perdata Yang Hukumnya Tidak Jelas, Jurnal Hukum Prioris Vol 6 No 1 Fakultas Hukum Trisakti Jakarta, 2017, Jakarta.

${ }^{5}$ Jemmy Saut, Tinjauan Hukum Tentang Putusan Hakim Perkara Perdata Terhadap Proses Mediasi, Jurnal Lex Administratum Vol 3 No 5, Fakultas Hukum Universitas Sam Ratulangi, 2015 Manado.
} 
proses mediasi, banyak hambatan dan kendala-kendala yang menyertainya. Hambatan tersebut diantaranya kurangnya keterbukaan para pihak dalam mediasi, sikap para pihak yang tidak mau saling mengalah, ketidakhadiran para pihak dalam proses mediasi, kurangnya iktikad baik para pihak, peran kuasa hukum, kurangnya kemampuan hakim dalam memimpin jalannya mediasi, ketidaknetralan mediator, dan lain sebagainya. ${ }^{6}$

Sedangkan penelitian yang dilakukan oleh Made Oka Cahyadi Wiguna (2018) mengkaji mengenai peluang penyelesaian sengketa perdata tentang tanah melalui alternativ dispute resolution. Penelitian tersebut jelaskan bagaimana keadilan dan kepuasan para pihak yang bersengketa sulit terwujud apabila jalur penyelesainnya melalui litigasi atau pengadilan. Bagaimana pilihan hukum yang dapat dipilih dalam penyelesaian sengketa perdata pertanahan adalah melalui alternatif penyelesaian sengketa. Penyelesaian sengketa dengan cara ini harus secara suka rela disepakati para pihak sebagai pilihan hukum dan mengikat para pihak seperti halnya sebagai suatu perjanjian. Alternatif penyelesaian sengketa yang hanya dapat diselesaikan oleh para pihak yang bersengketa dapat berjalan dengan baik apabila para pihak yang bersengketa berkomitmen melaksanakan apa yang menjadi keputusan bersama dalam penyelesaian sengketa. Penyelsaaian sengketa dengan model ini dipilih karena lebih cepat, murah dan tetap terjaga hubungan yang baik diantara para pihak yang bersengketa. ${ }^{7}$

Ketika sebuah masyarakat bernegara, maka harus ada persamaan pikir dan sikap masyarakat pada negara. Harus meletakkan setiap egonya pada prinsip yang telah disepakati bersama dan menjunjung tinggi prinsip dasar

${ }^{6}$ Ade Adriansyah, Kedudukan Hukum Putusan No. 200/Pdt. G/2008/PN. SMG Dalam Penyelesaian Sengketa Kepemilikan Tanah Melalui Pendekatan Restorative, Jurnal Ius Constituendum Vol 3 No 1, Magister Hukum Universitas Semarang, 2018, Semarang, hal 9. DOI : $\underline{10.26623 / \text { jic.v3i1.860 }}$

${ }^{7}$ Made Oka Cahyadi Wiguna, Peluang Penyelesaian Sengketa Perdata Tentang Tanah Melalui Alternative Dispute Resolution, Jurnal Masalah Maslah Hukum Vol 47 No 1, Fakultas Hukum Universita Diponegoro, 2018, Semarang hal 47-55. DOI: $10.14710 / \mathrm{mmh} \cdot 47.1 .2018 .47-55$ 
tersebut demi terciptanya rasa aman bermasyarakat dan tercapainya tujuan bernegara yaitu kemakmuran. Prinsip dasar Negara Kesatuan Republik Indonesia adalah Pancasila yang mengakomodir dan (harusnya) juga bersifat memaksa sebagai pandangan hidup semua orang yang mengaku Bangsa Indonesia dan menjadi sifat dasar bagi semua rakyat Indonesia dalam bermasyarakat dengan mengamalkan butir-butir Pancasila.

Penelitian ini melengkapi penelitian sebelumnya yang mengkaji tentang penyelesaian sengketa perdata baik melalui litigasi maupun non litigasi, penelitian ini fokus pada bagaimana sistem hukum Pancasila sebagai prinsip hakim dalam memutus perkara sengketa para pihak. Bagaimana nilai keadilan yang ada dalam 2 butir sila Pancasila yaitu Kemanusiaaan yang Adil dan Beradab dan sila ke 5 Keadilan Sosial Bagi Seluruh Rakyat Indonesia menjadi nilai bagi hakim dalam memutus sengketa perkara perdata. Hakim dalam memutus perkaranya tidak terjebak pada positivisme hukum tetapi dalam memutus perkaranya hakim wajib menggali dan mencari nilai-nilai yang ada dan tumbuh dalam masyarakat dalam memutus suatu perkara hukum. Tujuan dari penelitian ini adalah untuk mengkaji bagaimana sistem hukum Pancasila sebagai prinsip pertimbangan halkim dalam memutus perkara perdata dan bagaimana rekonstruksi prinsip pertimbangan hakim terhadap sengketa para pihak,

\section{B. Rumusan Masalah}

Berdasarkan latar belakang di atas dapat dirumuskan beberapa permasalahan yang akan dikaji dalam tulisan ini, sebagai berikut:

1. Bagaimana sistem hukum Pancasila sebagai prinsip pertimbangan hakim terhadap sengketa para pihak?

2. Bagaimana rekonstruksi prinsip pertimbangan hakim terhadap sengketa para pihak berbasis nilai keadilan?

\section{Metodelogi Penelitian}

Penelitian ini dimaksudkan untuk menganalisis tentang bentuk perwujudan kepastian hukum, keadilan dan kemanfaatan dalam putusan hakim di peradilan perdata, dengan mengacu kepada peraturan-peraturan 
yang ada sesuai dengan bidang kajian ilmu hukum di dalam meneliti bahan pustaka atau data sekunder. Metode penelitian yang digunakan pada penelitian ini adalah Paradigma konstruktivisme, jenis penelitian hukum normatif dan penelitian hukum empiris. Paradigma konstruktivisme memandang hukum, termasuk dalam pengertian hukum di sini yaitu mediasi penal yang handak mengoreksi hukum dalam paradigma lama HIR RBg, yaitu perdamaian, bersifat plural dan plastis. Dikatakan plural karena hukum itu diekspresikan ke dalam berbagai simbol, bahasa dan wacana. Sifat plastis hukum diartikan sebagai sifat dari ciri hukum yang dapat dibentuk sesuai dengan kebutuhan, atau dalam istilah yang digunakan oleh peneliti yaitu sesuai dengan kemanfaatan bagi manusia dalam masyarakat. ${ }^{8}$ Pendekatan penelitian yang dilakukan terhadap permasalahan dalam penelitian ini menggunakan pendekatan yuridis sosiologis (sociolegal research), yang artinya dalam penelitian ini dilakukan pengkajian terhadap aturan-aturan, norma-norma yang berlaku dalam masyarakat dan penelitian diarahkan pada fungsi hukum dalam masyarakat dikaitkan dengan hukum nasional positif yang berlaku di Indonesia.

\section{PEMBAHASAN}

\section{Sistem Hukum Pancasila Sebagai Prinsip Pertimbangan Hakim Terhadap Sengketa Para Pihak}

Dalam memutus perkara yang terpenting adalah kesimpulan hukum atas fakta yang terungkap dipersidangan. Untuk itu hakim harus menggali nilai-nilai, mengikuti, dan memahami nilai-nilai hukum dan rasa keadilan yang hidup dalam masyarakat. ${ }^{9}$ Sumber hukum yang dapat diterapkan oleh hakim dapat berupa peraturan perundang-undangan berikut peraturan

${ }^{8}$ Teguh Prasetyo dan Abdul Halim Barkatullah, Ilmu Hukum dan Filsafat Hukum Studi Pemikiran Ahli Hukum Sepanjang Zaman, Cetakan Keempat, Pustaka Pelajar, 2011, Yogyakarta, hal 325.

${ }^{9}$ Lihat Pasal 5 UU No. 48 Tahun 2009 Tentang Kekuasaan Kehakiman. 
pelaksanaannya, hukum tidak tertulis (hukum adat), putusan desa, yurisprudensi, ilmu pengetahuan maupun doktrin/ajaran para ahli. ${ }^{10}$

Sebagai suatu produk hukum dalam Sistem Hukum Pancasila, sudah barang tentu Undang-Undang Kekuasaan Kehakiman tidak dapat dilepaskan dari Pancasila sebagai sumber dari segala sumber hukum. Hal itu terbukti, bahwa sama dengan undang-undang lainnya dalam Sistem Hukum Pancasila, keberadaan Undang-Undang Kekuasaan Kehakiman di dalamnya berisi pengakuan bahwa keberadaan undang-undang tersebut merupakan suatu rahmat dari Tuhan Yang Maha Esa. Prinsip ini memiliki basis filosofis yang kuat dalam sila pertama Pancasila, sebagaimana dirumuskan dalam Pembukaan Undang-Undang Dasar Negara Republik Indonesia Tahun 1945. Dalam konteks pembicaraan mengenai pertimbangan hakim terhadap sengketa para pihak dalam Sistem Hukum Indonesia, maka prinsip pertimbangan hakim terhadap sengketa para pihak juga wajib tunduk pada sila pertama Pancasila, yaitu Ketuhanan Yang Maha Esa.

Dengan perkataan lain, prinsip pertimbangan hakim terhadap sengketa para pihak adalah prinsip-prinsip yang mengakui adanya kekuasaan Tuhan Yang Maha Esa di dalamnya. Suatu prinsip yang membuktikan bahwa apa pun kaidah dan asas hukum yang berlaku dalam Sistem Hukum Pancasila tidak dapat dilepaskan jiwanya dari jiwa yang mengakui kekuasaan Tuhan Yang Maha Esa.

Hukum positif merupakan salah satu hasil dari kegiatan manusia dalam negara sebagai co-eksistensietis, sedangkan hukum itu berasal dari kehendak yuridis dan politis, tetapi kehendak yuridis dan politis itu merupakan bagian kehendak etis manusia untuk mengatur kehidupan bersama dalam segala relasi-relasinya agar relasi-relasi itu baik dan karenanya kehidupan manusia sendiri-sendiri menjadi baik dan bahagia. Dapat pula dikatakan bahwa hukum itu terkait dengan etika, sebab melalui norma-norma hukum ditetapkan suatu

\footnotetext{
${ }^{10}$ R. Soeparmono, Hukum Acara Perdata dan Yurisprudensi, Mandar Maju, 2005, Bandung, hal. 146.
} 
tatanan sosial yang adil. Hukum mewajibkan secara etis dan yuridis, sebab hukum menciptakan keadilan.

Penegakan hukum yang mengutamakan kepastian hukum merupakan pandangan legisme yang berlebihan, menjadi kendala masuknya asas-asas hukum dan nilai (keadilan) yang hendak ditegakkan oleh hukum ke dalam putusan pengadilan. Penegakan hukum yang mengabaikan nilai keadilan dapat menjauhkan cita rasa keadilan masyarakat dan pada gilirannya akan memengaruhi citra hukum dan penegakan hukum di mata masyarakat. ${ }^{11}$

Di dalam Pancasila kata adil terdapat pada sila kedua, Kemanusiaan yang adil dan beradab, disamping itu juga termuat dalam sila kelima, Keadilan Sosial bagi seluruh rakyat Indonesia. Nilai kemanusiaan yang adil dan keadilan sosial mengandung suatu makna bahwa hakika tmanusia sebagai makhluk yang berbudaya dan berkodrat harus berkodrat adil, yaitu adil dalam hubungannya dengan diri sendiri, adil terhadap manusia yang lain, adil terhadap masyarakat bangsa dan negara, adil terhadap lingkungannya serta adil terhadap Tuhan Yang Maha Esa.

Pancasila sebagai dasar negara merupakan unsur-unsur pokok dalam kaidah negara yang fundamental, merupakan norma hukum yang pokok, sehingga semua perundang-undangan yang ada baik tertulis maupun tidak tertulis serta putusan hakim tidak boleh bertentangan dengan Pancasila yang berisi nilai-nilai Ketuhanan Yang Maha Esa, Kemanusiaan Yang Adil dan Beradab, Persatuan Indonesia, Kerakyatan yang dipimpin oleh Hikmat Kebijaksanaan dalam Permusyawaratan/Perwakilan, dan Keadilan Sosial bagi Seluruh Rakyat Indonesia.

\footnotetext{
${ }^{11}$ Dedy Muchti Nugroho, Penemuan Hukum Oleh Hakim Dalam Perkara Perdata Berdasar Asas Peradilan Yang Baik, Jurnal Jurnal Ilmu Hukum QISTIE Vol 10 No 1, Fakultas Hukum Universitas Wahid Hasyim, 2015, Semarang, hal 14. DOI: http://dx.doi.org/10.31942/jqi.v10i1.1962
} 
Keadilan sosial dalam butir pengamalan Pancasila seperti yang tertuang dalam P4 (Pedoman Penghayatan dan Pengamalan Pancasila) pada Tap MPR No. I/MPR/2003. Keadilan Sosial Bagi Seluruh Rakyat Indonesia. ${ }^{12}$

Seorang hakim harus menjaga dirinya agar tidak berbuat salah serta selalu menjagatingkah laku dan budi pekertinya. Tidaklah mengherankan apabila seorang hakim berbuat salah atau bertingkah laku yang tidak baik/tercela, reaksi masyarakat akan lebih keras apabila hal itu dilakukan oleh seorang yang bukan hakim.

\section{Rekonstruksi Prinsip Pertimbangan Hakim Terhadap Sengketa Para} Pihak Berbasis Nilai Keadilan

\section{a. Rekonstruksi Nilai}

Sering dijumpai di pengadilan bahwa putusan hakim perdata tersebut belum dapat mengakomodir kedua belah pihak meskipun salah satupihak dinyatakan sebagai perbuatan melawan hukum dan/atau wanprestasi, akan tetapi dalam pemenuhan kerugiannya masih memberatkan pihak yang kalah sehingga pihak yang kalah tersebut tidak terima terhadap putusan tersebut dan mengajukan upaya hukum. Oleh karena hakim harus dapat mempertimbangkan segala aspek baik dari sisi Penggugat maupun Tergugat sehingga ketika hakim menjatuhkan putusan, daripihak yang dikalahkan tidak menjadi semakin menjadi kalah dan putusan tersebut pihak yang kalah tidak dihukum terlalu tinggi dan tidak memberatkan.

Hakim tidak saja dituntut untuk memahami hukum yang telah dipositifkan, tetap lebih dari sekedar itu hakim harus pula memahami makna yang terkandung dibalik hukum yang telah dipositifkan tersebut, karena hakim memainkan peran sentral dalam proses komunikasi di pengadilan melalui interpretasi. Untuk dapat melaksanakan tugasnya yang luhur namun sangat berat, (karena sering harus menghadapi berbagai tantangan dan godaan dalam masyarakat,) maka hakim harus dibekali dengan ketangguhan moral,

${ }^{12}$ Ibid. 
kaidah-kaidah penuntun dan aturan-aturan tentang perilaku yang seharusnya dipegang teguh oleh seorang hakim dalam menjalankan tugas dan kewajibannya. $^{13}$

Putusan Hakim yang diopinikan sebagai "cacat hukum". Bagi pihak yang memahami aturan hukum tetap memegang prinsip, bahwa Legalitas Putusan Hakim yang telah berkekuatan hukum yang tetap (In kracht van gewijsde) dianggap benar. Dan jika "dictum" putusan mengandung sifat "penghukuman/ comdemnatoir", maka putusan a quo harus dilaksanakan sesuai aturan hukum yang berlaku. Mereka ini sadar, bahwa putusan hakim di tingkat pertama telah diuji melalui upaya hukum (Banding, Kasasi dan Peninjuauan Kembali (PK)), dan kalaupun ada pihak yang merasa dirugikan akibat eksekusi, maka saluran hukum yang tepat untuk membuktikan kebenarannya tetap terbukanya saluran hukum bagi setiap orang/ pihak berupa pengajuan gugatan perdata biasa (jika ekseksusi telah terlaksana).

Dalam memutus perkara yang terpenting adalah kesimpulan hukum atas fakta yang terungkap dipersidangan. Seorang hakim sebelum melaksanakan tugasnya yaitu membuat putusan atas perkara yang ditanganinya, tidak boleh memutuskan begitu saja tanpa memberikan argumentasi hukum atau pertimbangan hukum atau legal reasoning, sehingga keputusan yang akan dijatuhkan dapat didasari oleh rasa tanggung jawab, keadilan, kebijaksanaan, profesionalisme dan bersifat obyektif. ${ }^{14}$

Pertimbangan hakim yang ideal, bahwa Legal reasoning hakim dalam pengambilan putusan perkara di pengadilan harus adanya persesuaian secara yuridis antara fakta hukum, alat bukti dan dasar hukum peraturan perundang-

${ }^{13}$ Firman A. Mulingka, Fungsi Dan Kedudukan Hakim Dalam Sistem Peradilan Pidanan Kaitannya Dengan Kemandirian Hakim, Jurnal Lex Administratum, Vol. 3 No. 6, Fakultas Hukum Universitas Sam Ratulangi, 2015, Manado, hal 34.

${ }^{14}$ Nur Iftitah Isnantiana, Legal Reasoning Hakim Dalam Pengambilan Putusan Perkara Di Pengadilan, Jurnal Islamadina Vol. 28 No. 2, Fakultas Hukum Universitas Muhammadiyah Purwokerto, 2017, Purwokerto, hal 54. http://dx.doi.org/10.30595/islamadina.v18i2.1920 
undangan. ${ }^{15}$ Fakta hukum diperlukan sebagai dasar pokok gugatan (fundamentum petendi). Apakah telah didukung dengan adanya alat bukti (pasal 164 HIR, pasal 284 RBg, Pasal 1866 KUHPerdata) sebagai dasar pembuktian dan dasar hukum peraturan perundangan merupakan dimensi ratio decidendi atau legal reasoning? Hakim menyatakan suatu perkara terbukti atau tidak, dan akhirnya memenangkan salah satu pihak berperkara, atau mengabulkan/menolak suatu gugatan. ${ }^{16}$

Putusan perdata itu harus dapat mengakomodir kedua belah pihak meskipun salah satu pihak dinyatakan sebagai perbuatan melawan hukum dan/atau wanprestasi, akan tetapi dalam pemenuhan kerugiannya tidak memberatkan pihak yang kalah sehingga pihak yang kalah tersebut tidak terima dan mengajukan upaya hukum. Hakim harus dapat mempertimbangkan segala aspek baik dari sisi Penggugat maupun Tergugat sehingga ketika hakim menjatuhkan putusan, pihak yang kalah tidak merasa sangat kalah.

Abdul Hakim (2017) pada penelitiannya yang mengupas tentang menakar rasa keadilan pada putusan hakim perdata berkesimpulan bahwa seorang hakim pada hakikinya bukan hanya sekedar melakukan perbuatan hukum berupa memeriksa, mengadili dan memutus perkara an sich, namun perbuatan hukum dari hakim tersebut berintikan kepada kegiatan ilmiah berupa interpretasi dan pemahaman. Sehingga, seharusnya hakim tidak terjebak dengan asas pasif dalam hokum acara perdata. ${ }^{17}$

Penemuan hukumnya suatu kejadian atau peristiwa dengan cara menerapkan peraturan-peraturan hukum yang berlaku adalah suatu hal yang

\footnotetext{
${ }^{15}$ Hasil wawancara dengan DR. Lilik Mulyadi, S.H., M.H., Hakim Tinggi pada Balitbang Diklatkum di Mahkamah Agung Republik Indonesia, pada tanggal 28 April 2019 di Mahkamah Agung Republik Indonesia.

${ }^{16}$ Ibid.

17 Abdul Hakim, Menakar Rasa Keadilan Pada Putusan Hakim Perdata Terhadap Pihak Ketiga Yang Bukan Pihak Berdasarkan Perspektif Negara Hukum Pancasila, Jurnal Hukum dan Peradilan Vol 6 No 3, Mahkamah Agung RI, 2017, Jakarta, hal 361-378. http://doi.org/10.25216/jhp.6.3.2017.361-378
} 
sangat wajar. Pada kenyataannya, bahwa penemuan hukum tersebut bukanlah sekedar menerapkan peraturan-peraturan hukum yang telah ada dan berlaku saja, akan tetapi kemudian berupaya menciptakan hukumnya sendiri apabila peraturan-peraturan hukumnya tidak jelas, tidak tegas ataupun peraturanperaturan hukumnya tidak ada.

Selama ini pola pikir hakim dalam penemuan hukum masih terbelenggu legalitas formal atau keadilan formal. Penemuan hukum menghasilkan keadilan cenderung melukai rasa keadilan masyarakat. Proses penemuan hukum yang berkeadilan hanya sebatas berdasarkan undang-undang, padahal rasa keadilan bisa saja ditemukan di luar undang-undang. ${ }^{18}$

Melihat kepentingan tergugat yang tidak masuk kategori ultra petita, yaitu di luar batas dari apa yang dituntut, yaitu melihat apa yang dijawab di terhadap gugatan penggugat itu sebenarnya mempunyai kepentingan yang sama, hanya biasanya penggugat meminta lebih, sedangkan tergugat tidak mau semua. Disitu dapat dilihat bahwa seandainya kepentingan maupun dari penggugat apa yang diminta dan apa yang dibantah oleh tergugat bisa dipertemukan/disatukan dengan melihat kondisi dari penggugat dan tergugat sendiri dan itu kemudian diakomodir dalam suatu pertimbangan putusan, hal tersebut sebenarnya bisa membuat masing-masing para pihak menjadi puas.

\section{b. Temuan Teori Hukum Baru}

Hakim dalam menyelesaikan konflik yang dihadapkan kepadanya harus dapat menyelesaikan secara obyektif berdasarkan hukum yang berlaku, maka dalam proses pengambilan keputusan, para hakim harus mandiri dan bebas dari pengaruh pihak manapun, termasuk dari eksekutif. Dalam pengambilan keputusan, para hakim hanya terikat pada fakta-fakta yang relevan dan kaidah hukum yang menjadi atau dijadikan landasan hukum keputusannya. Tetapi penentuan fakta-fakta yang termasuk fakta-fakta yang relevan dan pilihan

18 Muhammad Helmi, Penemuan Hukum oleh Hakim Berdasarkan Paradigma Konstruktivisme, Kanun Jurnal Ilmu Hukum Vol. 22, No. 1, Fakultas Hukum Universitas Syiah Kuala, 2020, Banda Aceh, hal 113. DOI: https://doi.org/10.24815/kanun.v22i1.14792 
kaidah hukum yang mana yang akan dijadikan landasan untuk menyelesaikan kasus yang dihadapinya diputuskan oleh hakim yang bersangkutan sendiri. ${ }^{19}$

Hakim sebagai pelaksana kekuasaan kehakiman yang mempunyai tugas untuk memutus suatu perkara dengan memberikan rasa keadilan memiliki beberapa bentuk pertanggungjawaban dalam mengadili suatu perkara yaitu tanggung jawab kepada Tuhan Yang Maha Esa, tanggung jawab pada bangsa dan Negara, tanggung jawab kepada diri sendiri, tanggung jawab kepada hukum, tanggung jawab kepada para pencari keadilan, dan tanggung jawab kepada masyarakat. untuk itu hakim diharapkan dapat menggali dan menafsirkan undang-undang untuk menciptakan hukum yang memberikan rasa keadilan dan kepastian hukum kepada masyarakat dan pencari keadilan. Bertanggungjawab bermakna kesediaan dan keberanian untuk melaksanakan sebaik-baiknya segala sesuatu yang menjadi wewenang dan tugasnya. ${ }^{20}$

Teori keadilan bermartabat dikemukakan oleh Teguh Prasetyo, disebut bermartabat karena teori dimaksud adalah merupakan suatu bentuk pemahaman dan penjelasan yang memadai (ilmiah) mengenai koherensi dari konsep-konsep hukum di dalam kaidah dan asas-asas hukum yang berlaku serta doktrin-doktrin yang sejatinya merupakan wajah, struktur atau susunan dan isi serta ruh atau roh (the spirit) dari masyarakat dan bangsa yang ada di dalam sistem hukum berdasarkan Pancasila, yang dijelaskan oleh teori keadilan bermartabat itu sendiri. ${ }^{21}$

Teori keadilan bermartabat, merupakan suatu hasil pergumulan pemikiran filsafat yang dilakukan secara terus-menerus. Penelusuran terhadap sumber dimana teori ini mulai digagas ditemukan bahwa teori

${ }^{19}$ Firman Floranta Adonara, Prinsip Kebebasan Hakim dalam Memutus Perkara Sebagai Amanat Konstitusi, Jurnal Konstitusi, Vol 12, No 2, Mahkamah Konstitusi, 2015, Jakarta, hal 218-219.

DOI: https://doi.org/10.31078/jk1222

20 Annisa, FN. Peranan Hakim sebagai Penegak Hukum Berdasarkan UndangUndang Nomor 48 Tahun 2009 tentang Kekuasaan Kehakiman. Jurnal Lex et Societatis Vol 5, No 3, Fakultas Hukum Universitas Sam Ratulangi, 2017, Manado, hal 164.

${ }^{21}$ Teguh Prasetyo, Keadilan Bermartabat, Perspektif Teori Hukum, Nusamedia, 2015, Bandung, hlm 63. 
keadilan bermatabat adalah teori hukum yang dibangun atas dasar pemahaman bahwa menyelami pikiran tentang teori dan paradigm hukum yang dikemukakan oleh para pakarnya haruslah dirunut dan diteliti dari latar belakang politik dan kondisi sosial masyarakat tempat ahli pikir tersebut hidup, sehingga bisa ditentukan paradigma yang diajukan oleh ahli pikir tersebut masih relevan atau tidak dalam memahami hukum pada saat ini dengan kondisi dan struktur sosial yang sangat berbeda dengan latar belakang sosial dimana paradigma tersebut diajukan oleh ahlinya.

Memperhatikan postulat dasar pengajuan teori sebagaimana dikemukakan oleh penggagas teori keadilan bermartabat di atas, dapat diketahui bahwa teori keadilan bermartabat adalah suatu alat atau instrument filsafati yang dibuat dengan sengaja, hasil dari proses berpikir untuk menemukan kebenaran yang sangat panjang dalam rangka melakukan analisis dan justifikasi terhadap gejala hukum. Dalam konteks penelitian ini, teori keadilan bermartabat merupakan hasil pemikiran secara terus menerus dalam menjelaskan prinsip pertimbangan hakim terhadap sengketa para pihak dalam sistem hukum Indonesia dengan berbasis nilai keadilan.

Menurut Teguh Prasetyo, sistem hukum nasional Indonesia yang dibentuk dan diberlakukan seyogyanya adalah sistem hukum Indonesia sendiri, yaitu suatu sistem yang dibangun dari proses penemuan, seperti yang dilakukan melalui penelitian ini, pengembangan, adaptasi, bahkan kompromi dari berbagai sistem yang telah ada. Kaitan dengan itu, dalam konteks teori keadilan bermartabat, hukum yang identik dengan keadilan (justice) sebagai suatu sistem, dalam hal ini sistem hukum Indonesia setidak-tidaknya harus bersumber dari bumi Indonesia sendiri. Fraseologi bumi Indonesia yang dipergunakan dalam teori keadilan bermartabat dimaksud sejatinya merupakan analogi dari pikiran orang Indonesia sendiri.

Ruang lingkup teori keadilan bermartabat tidak hanya pengungkapan dimensi yang abstrak dari kaidah dan asas-asas hukum yang berlaku. Lebih jauh dari pada itu, teori keadilan bermartabat mengungkap pula semua kaidah dan asas-asas hukum yang berlaku di dalam sistem hukum, dalam hal ini 
sistem hukum dimaksud sistem hukum positif Indonesia; atau sistem hukum berdasarkan Pancasila. Itusebabnya, Keadilan Bermartabat, sebagai suatu teori hukum berdasarkan Pancasila.

Secara garis besar, sistem dalam teori keadilan bermartabat merupakan satu dari postulat penting teori dimaksud. Sistem yang diacu dalam teori ini pada menunjuk kepada wujudnya yang abstrak dan koseptual dan oleh sebab itu disebut dengan deskriptif. Deskripsi mengenai sistem itu susunan dasarnya dimulai dari Pancasila, dan selanjutnya diikuti dengan norma fundamental berupa Undang-Undang Dasar Negara Republik Indonesia Tahun 1945 beserta Ketetapan-Ketetapan MPR yang mengandemen Undang-undang Dasar Negara Republik Indonesia Tahun 1945 yang asli.

Keadilan menurut Pancasila tercantum pada sila kelima, yakni Keadilan Bagi Seluruh Rakyat Indonesia. Bangsa Indonesia harus benar-benar meresapi nilai-nilai yang terkandung dalam Pancasila, tentunya degradasi moral dan kebiadaban masyarakat kita dapat diminimalisir. Kenyataannya sekarang yaitu setelah era reformasi, para reformator alergi dengan semua produk yang berbau orde baru termasuk P4 sehingga terkesan meninggalkannya begitu saja. Belum lagi saat ini jati diri Indonesia mulai goyah ketika sekelompok pihak mulai mementingkan dirinya sendiri untuk kembali menjadikan negara ini sebagai negara berideologi agama tertentu.

Sebagai suatu produk hukum dalam Sistem Hukum Pancasila, sudah barang tentu Undang-Undang Kekuasaan Kehakiman tidak dapat dilepaskan dari Pancasila sebagai sumber dari segala sumber hukum. Hal itu terbukti, bahwa sama dengan undang-undang lainnya dalam Sistem Hukum Pancasila, keberadaan Undang-Undang Kekuasaan Kehakiman di dalamnya berisi pengakuan bahwa keberadaan undang-undang tersebut merupakan suatu rahmat dari Tuhan Yang Maha Esa. Prinsip ini memiliki basis filosofis yang kuat dalam sila pertama Pancasila, sebagaimana dirumuskan dalam Pembukaan Undang-Undang Dasar Negara Republik Indonesia Tahun 1945. Dalam konteks pembicaraan mengenai pertimbangan hakim terhadap sengketa para pihak dalam Sistem Hukum Indonesia, maka prinsip 
pertimbangan hakim terhadap sengketa para pihak juga wajib tunduk pada sila pertama Pancasila, yaitu Ketuhanan Yang Maha Esa.

Pemikiran hukum perlu kembali pada filosofis dasarnya, yaitu hukum untuk manusia. Dengan filosofis tersebut, maka manusia menjadi penentu dan titik orientasi hukum. Hukum bertugas melayani manusia, bukan sebaliknya. Oleh karena itu, hukum itu bukan merupakan institusi yang lepas dari kepentingan manusia. Mutu hukum ditentukan oleh kemampuannya untuk mengabdi pada kesejahteraan manusia. Ini menyebabkan hukum progresif menganut "ideologi" : Hukum yang pro-keadilan dan Hukum yang prorakyat.

Dalam logika itulah revitalisasi hukum dilakukan setiap kali. Bagi hukum progresif, proses perubahan tidak lagi berpusat pada peraturan, tetapi pada kreativitas pelaku hukum mengaktualisasikan hukum dalam ruang dan waktu yang tepat. Para pelaku hukum progresif dapat melakukan perubahan dengan melakukan pemaknaan yang kreatif terhadap peraturan yang ada, tanpa harus menunggu perubahan peraturan (changing the law). Peraturan buruk tidak harus menjadi penghalang bagi para pelaku hukum progresif untuk menghadirkan keadilan untuk rakyat dan pencari keadilan, karena mereka dapat melakukan interprestasi secara baru setiap kali terhadap suatu peraturan.

\section{PENUTUP}

Sebagai suatu produk hukum dalam Sistem Hukum Pancasila, sudah barang tentu Undang-Undang Kekuasaan Kehakiman tidak dapat dilepaskan dari Pancasila sebagai sumber dari segala sumber hukum. Hal itu terbukti, bahwa sama dengan undang-undang lainnya dalam Sistem Hukum Pancasila, keberadaan Undang-Undang Kekuasaan Kehakiman di dalamnya berisi pengakuan bahwa keberadaan undang-undang tersebut merupakan suatu rahmat dari Tuhan Yang Maha Esa. Prinsip ini memiliki basis filosofis yang kuat dalam sila pertama Pancasila, sebagaimana dirumuskan dalam Pembukaan Undang-Undang Dasar Negara Republik Indonesia Tahun 1945. Dalam konteks pembicaraan mengenai pertimbangan hakim terhadap sengketa para 
pihak dalam Sistem Hukum Indonesia, maka prinsip pertimbangan hakim terhadap sengketa para pihak juga wajib tunduk pada sila pertama Pancasila, yaitu Ketuhanan Yang Maha Esa. Rekonstruksi nilai dalam Pasal 5 ayat (1) Undang-Undang Nomor 48 Tahun 2009, "Hakim dan hakim konstitusi wajib menggali, mengikuti, dan memahami nilai-nilai hukum dan rasa keadilan yang hidup dalam masyarakat". Dalam Pasal tersebut mewajibkan hakim sebagai penegak hukum dan keadilan untuk menggali dan memahami nilai-nilai hukum yang hidup dalam masyarakat. Pada prinsipnya hakim tidak diberi wewenang untuk mengubah suatu undang-undang akan tetapi hakim guna menjatuhkan putusannya yang berdasar pada perkembangan kehidupan dalam masyarakat dengan tidak menerapkan undang-undang tersebut. Merekonstruksi Norma Hukum dalam Pasal 5 Ayat (1) Undang-Undang Nomor 48 Tahun 2009 Tentang Kekuasaan Kehakiman, Menjadi berbunyi: Hakim dan hakim konstitusi wajib menggali, mengikuti, dan memahami nilai-nilai hukum dengan cara merekonstruksi hukum, menafsirkan hukum, dan menemukan hukum untuk memberi rasa keadilan yang hidup dalam masyarakat.

\section{DAFTAR PUSTAKA}

\section{Buku}

Kuffal, HMA. Demi Keadilan Berdasarkan Ketuhanan Yang Maha Esa Hakim: Antara Gaji, Keadilan,Kejujuran dam Ketaqwaan, UMM Press. 2012, Malang.

R. Soeparmono, Hukum Acara Perdata dan Yurisprudensi, Mandar Maju,2005, Bandung.

Teguh Prasetyo dan Abdul Halim Barkatullah, Ilmu Hukum dan Filsafat Hukum Studi Pemikiran Ahli Hukum Sepanjang Zaman, Cetakan Keempat, Pustaka Pelajar, 2011, Yogyakarta,

Teguh Prasetyo, Keadilan Bermartabat, Perspektif Teori Hukum, Nusamedia, 2015, Bandung.

Wildan Suyuti Mustofa, Kode Etik Hakim, Kencana Prenadamedia Group, 2013, Jakarta. 


\section{Jurnal}

Ade Adriansyah, Kedudukan Hukum Putusan No. 200/Pdt. G/2008/PN. SMG Dalam Penyelesaian Sengketa Kepemilikan Tanah Melalui Pendekatan Restorative, Jurnal Ius Constituendum Vol 3 No 1, Magister Hukum Universitas Semarang, 2018, Semarang, hal 9. DOI $: \underline{10.26623 / j i c . v 3 i 1.860}$

Abdul Hakim, Menakar Rasa Keadilan Pada Putusan Hakim Perdata Terhadap Pihak Ketiga Yang Bukan Pihak Berdasarkan Perspektif Negara Hukum Pancasila, Jurnal Hukum dan Peradilan Vol 6 No 3, Mahkamah Agung RI, 2017, Jakarta. http://doi.org/10.25216/jhp.6.3.2017.361-378

Annisa, FN. Peranan Hakim sebagai Penegak Hukum Berdasarkan UndangUndang Nomor 48 Tahun 2009 tentang Kekuasaan Kehakiman. Jurnal Lex et Societatis Vol 5, No 3, Fakultas Hukum Universitas Sam Ratulangi, 2017, Manado.

Dedy Muchti Nugroho, Penemuan Hukum Oleh Hakim Dalam Perkara Perdata Berdasar Asas Peradilan Yang Baik, Jurnal Jurnal Ilmu Hukum QISTIE Vol 10 No 1, Fakultas Hukum Universitas Wahid Hasyim, 2015, Semarang. http://dx.doi.org/10.31942/jqi.v10i1.1962

Firman A. Mulingka, Fungsi Dan Kedudukan Hakim Dalam Sistem Peradilan

Pidanan Kaitannya Dengan Kemandirian Hakim, Jurnal Lex Administratum, Vol. 3 No. 6, Fakultas Hukum Universitas Sam Ratulangi, 2015, Manado.

Jemmy Saut, Tinjauan Hukum Tentang Putusan Hakim Perkara Perdata Terhadap Proses Mediasi, Jurnal Lex Administratum Vol 3 No 5, Fakultas Hukum Universitas Sam Ratulangi, 2015 Manado.

Made Oka Cahyadi Wiguna, Peluang Penyelesaian Sengketa Perdata Tentang Tanah Melalui Alternative Dispute Resolution, Jurnal Masalah Maslah Hukum Vol 47 No 1, Fakultas Hukum Universitas Diponegoro, 2018, Semarang.

DOI: $10.14710 / \mathrm{mmh} .47 .1 .2018 .47-55$

Muhammad Helmi, Penemuan Hukum oleh Hakim Berdasarkan Paradigma Konstruktivisme, Kanun Jurnal Ilmu Hukum Vol. 22, No. 1, Fakultas Hukum Universitas Syiah Kuala, 2020, Banda Aceh, hal 113. DOI: https://doi.org/10.24815/kanun.v22i1.14792

Ning Adiasih, Analisis Terhadap Putusan Pengadilan Dalam Perkara Perdata Yang Hukumnya Tidak Jelas, Jurnal Hukum Prioris Vol 6 No 1 Fakultas Hukum Trisakti Jakarta, 2017, Jakarta.

Nur Iftitah Isnantiana, Legal Reasoning Hakim Dalam Pengambilan Putusan Perkara Di Pengadilan, Jurnal Islamadina Vol. 28 No. 2, Fakultas Hukum Universitas Muhammadiyah Purwokerto, 2017, Purwokerto. http://dx.doi.org/10.30595/islamadina.v18i2.1920

Sri Hartini, Setiati Widihastuti, dan Iffah Nurhayati, Eksekusi Putusan Hakim Dalam Sengketa Perdata Di Pengadilan Negeri Sleman, Jurnal Civics Vol14 N0 2 Oktober 2017, Fakultas Ilmu Sosial Universitas Negeri 
p-ISSN : 2541-2345, e-ISSN : 2580-8842

Yogyakarta, 2017, Yogyakarta, hal 128.129. DOI: https://doi.org/10.21831/civics.v14i2.16852

\section{Undang-Undang}

UU No. 48 Tahun 2009 Tentang Kekuasaan Kehakiman. 